\title{
Kualitas Pelayanan dan Kinerja Pegawai terhadap Kepuasan Masyarakat di Unit Pelayanan Terpadu Satu Atap Kementerian Ketenagakerjaan
}

\author{
Eigis Yani Pramulaso \\ Universitas Bina Sarana Informatika \\ e-mail:eigis.eyp@bsi.ac.id

\begin{tabular}{ccc}
\hline Diterima & Direvisi & Disetujui \\
$22-01-2020$ & $13-02-2020$ & $25-02-2020$ \\
\hline
\end{tabular}

\begin{abstract}
Abstrak - Pemerintah sebagai pelayan masyarakat terus berupaya membuat persepsi positif dengan terus meningkatkan kepuasan masyarakat terkait dengan berbagai pelayanan yang dapat diberikan. Kepuasan masyarakat diupayakan terus semakin meningkat dengan memberikan kualitas pelayanan yang terbaik dan terus mendorong kinerja pegawai menjadi lebih optimal dalam melaksanakan tugasnya. Penelitian ini bertujuan mengetahui pengaruh kualitas pelayanan dan kinerja pegawai terhadap kepuasan masyarakat di Unit Pelayanan Terpadu Satu Atap Kementerian Ketenagakerjaan. Sampel dalam penelitian ini berjumlah 45 orang dimana teknik pengambilannya dengan accidental sampling. Metode pengumpulan data menggunakan kuesioner yang diberikan kepada responden yang kebetulan datang di lokasi penelitian. Alat analisis data dalam penelitian ini memakai uji regresi dengan alat uji validitas dan reliabilitas yang dilakukan sebelumnya. Penelitian ini hasilnya adalah secara simultan dan parsial kualitas pelayanan dan kinerja pegawai memiliki pengaruh signifikan tehadap terhadap kepuasan masyarakat di Unit Pelayanan Terpadu Satu Atap Kementerian Ketenagakerjaan dimana nilai F hitung yang diperoleh sebesar 19,042 dan nilai sig 0,000.
\end{abstract}

Kata Kunci: Kualitas Pelayanan, Kinerja Pegawai, Kepuasan Masyarakat

Abstract - The government as a public servant continues to strive to make positive perceptions by continuing to improve community satisfaction related to the various services that can be provided. Community satisfaction is strived to continue to increase by providing the best quality of service and continue to encourage employee performance to be more optimal in carrying out their duties. This study aims to determine the effect of service quality and employee performance on community satisfaction in the One-Stop Integrated Services Unit of the Ministry of Manpower. The sample in this study amounted to 45 people where the technique was taken by accidental sampling. The data collection method uses a questionnaire given to respondents who happened to come at the research location. Data analysis tools in this study used a regression test with a validity and reliability test conducted previously. The results of this study are simultaneous and partial service quality and employee performance have a significant influence on community satisfaction in the One-Stop Integrated Services Unit of the Ministry of Manpower where the calculated F value is 19,042 and sig 0,000.

Keywords: Service Quality, Employee Performance, Community Satisfaction

\section{PENDAHULUAN}

Kepuasan yang dirasakan masyarakat menjadi salah satu ukuran kinerja yang dapat digunakan oleh instansi pemerintah dalam melaksanakan tugas dan kewajibannya. Berbagai persepsi masyarakat akan muncul dengan sendirinya setelah masyarakat berinteraksi langsung dalam memenuhi berbagai kepentingan yang terkait dengan intansi pemerintah. Menghadapi hal tersebut, instansi pemerintah sebagai pelayan masyarakat tentunya berusaha keras agar persepsi yang muncul bersifat positif atau dapat memberikan kepuasan terhadap masyarakat. Pelayanan yang ada seyogyanya sesuai dengan beberapa prinsip pelayanan umum yaitu kesederhanaan dimana prosedur pelayanan yang tidak berbelit-belit, mudah dipahami, dan mudah dilaksanakan, juga prinsip lainnya yaitu ketepatan waktu, dan akurasi yang berarti sesuai waktu pelayanan yang sudah ditentukan sebelumnya, dan hasil pelayanannya yang benar dan tepat (Kementerian Pendayagunaan Aparatur Negara Republik Indonesia, 2003).

Gambaran tentang kepuasan yang diterima masyarakat pada instansi pemerintah diantaranya dengan kualitas pelayanan yang diberikan. Kualitas yang pengelolaannya tepat dapat memberikan kontribusi positif terhadap terwujudnya kepuasan 
dan loyalitas pelanggan (Tjiptono, 2008). Dalam hal ini kualitas pelayanan yang diberikan berupa pemenuhan kebutuhan masyarakat yang optimal sesuai dengan standar dan prosedur yang ada yang diberikan pemerintah dan tentunya bagi pegawai juga sebagai bagian dalam melaksanakan tugas yang pelaksanaan pekerjaannya berdasar pada peraturan dan kebijakan yang berlaku.

Kepuasan masyarakat dapat juga dipengaruhi oleh kinerja pegawai yang terkait. Kinerja pegawai menjadi tolak ukur apa yang telah dilakukan sebagai pelaksana dalam kegiatan intansi pemerintah. Pegawai yang memiliki pemahaman yang baik terhadap tugas dan tanggap terhadap pemenuhan kebutuhan masyarakat tentunya sangat mendukung keberhasilan instansinya dalam memberikan pelayanan kepada masyarakat. Pendapat dari Armstrong dan baron dalam (Wibowo, 2009) menyatakan kinerja sebagai hasil dari suatu pekerjaan dimana berhubungan kuat dimana salah satunya yaitu kepuasan konsumen, selain kinerja itu juga memiliki tujuan strategis organisasi dan memberikan kontribusi ekonomi.

Salah satu upaya yang dilakukan Kementerian Ketenagakerjaan dalam meningkatkan kepuasan masyarakat diantaranya dengan memberikan kemudahan pelayanan dalam bentuk Pelayanan Terpadu Satu Atap (PTSA). Dalam pelayanan tersebut terdapat beberapa direktorat yang dinaungi oleh PTSA. Salah satu direktorat yang dinaungi oleh Pelayanan Terpadu Satu Atap adalah Ditjen Pembinaan Hubungan Industrial dan Jaminan Sosial Tenaga Kerja yang tugasnya menangani pengesahan tentang Peraturan Perusahaan dan Pendaftaran Perjanjian Kerja Bersama (Iqbal, 2016).

Penelitian dalam (Siswadhi, 2016) yang memiliki judul "Analisa Pengaruh Kualitas Pelayanan dan Kinerja Karyawan Badan Pertanahan Nasional Kabupaten Kerinci terhadap Kepuasan Masyarakat" menunjukkan variabel kualitas pelayanan dan kinerja karyawan Badan Pertanahan Nasional Kabupaten Kerinci secara simultan berpengaruh signifikan terhadap kepuasan masyarakat.

Hasil penelitian oleh (Noer \& Putri, 2013) yang berjudul "Pengaruh Kualitas Pelayanan dan Kinerja Karyawan Terhadap Kepuasan Pelanggan (Study pada Universitas Muhammadiyah Surakarta)" menunjukkan bahwa variabel kualitas pelayanan dan kinerja karyawan berpengaruh secara parsial dan simultan terhadap kepuasan pelanggan.

(Karyono \& Parman, 2016) melakukan penelitian dengan judul "Kepuasan Nasabah Diukur Dari Kinerja Pelayanan Dan Kinerja Karyawan” dimana hasilnya kepuasan nasabah dipengaruhi oleh kualitas pelayanan dan kinerja pegawai baik parsial maupun simultan.

Dalam penelitian (Kuncoro, 2017) bahwa kualitas pelayanan dan semangat kerja berpengaruh positif dan signifikan terhadap kepuasan masyarakat.
Penelitian (Ulumudin, 2014) menyatakan bahwa kepuasan masyarakat di Kecamatan Bayongbong terkait dengan administrasi kependudukan dipengaruhi oleh kualitas pelayanan yang ada.

Menurut Sinambela dalam (Hermawati, 2018) dalam definisi strategis dinyatakan bahwa "kualitas adalah segala sesuatu yang mampu memenuhi keinginanan atau kebutuhan pelanggan (meeting the needs of customers)". Morgan dan Murgatroyd dalam (Mukarom \& Laksana, 2015) berpendapat bahwa "Kualitas adalah bentuk-bentuk yang istimewa atau yang terbaik dari suatu hasil produksi atau pelayanan yang mempunyai kemampuan untuk memuaskan kebutuhan masyarakat”.

Menurut Ratminto dan Winarsih dalam (Hermawati, 2018) "pelayanan publik adalah sebagai segala bentuk jasa pelayanan yang menjadi tanggung jawab dan dilaksanakan instansi pemerintah di lingkungan Badan Usaha Milik Negara atau Badan Usaha Milik Daerah, untuk kebutuhan masyarakat maupun dalam rangka pelaksanaan ketentuan peraturan perundangundangan”. Menurut Pasuraman, Zeithaml, dan Berry dalam (Tjiptono, 2008) kualitas layanan memiliki dimensi utama meliputi reliability, responsiveness, assurance, empathy, dan tangibles.

Menurut (Mangkunegara, 2009) "kinerja SDM adalah prestasi kerja atau hasil kerja (output) baik kualitas maupun kuantitas yang dicapai SDM per satuan periode waktu dalam melaksanakan tugas kerjanya sesuai dengan tanggung jawab yang diberikan kepadanya”. Menurut (Prawirosentono, 1999) kinerja organisasi dapat dipengaruhi oleh faktor, efektivitas dan efisiensi, otoritas dan tanggung jawab, disiplin, dan inisiatif.

Kotler dalam (Putra, Pratiwi, \& Trisnawati, 2015) menyatakan "kepuasan merupakan perasaan senang atau kecewa seseorang yang berasal dari perbandingan antara kesannya terhadap kinerja atau hasil suatu produk dan harapan-harapannya”. Menurut (Ratminto \& Winarsih Atik Septi, 2015) dasar pengukuran indeks kepuasan dapat didasarkan pada prinsip pelayanan dalam Keputusan Menteri Pendayagunaan Aparatur Negara yang diatur dalam Nomor 63/KEP/M.PAN/7/2003.

Berikut hipotesis dalam penelitian ini:

$\mathrm{H}_{0}$ : Diduga tidak ada pengaruh signifikan kualitas pelayanan dan kinerja pegawai baik secara parsial maupun simultan terhadap kepuasan masyarakat di Unit Pelayanan Terpadu Satu Atap (PTSA) Kementerian Ketenagakerjaan.

$\mathrm{H}_{1}$ : Diduga ada pengaruh signifikan kualitas pelayanan dan kinerja pegawai baik secara parsial maupun simultan terhadap kepuasan masyarakat di Unit Pelayanan Terpadu Satu Atap (PTSA) Kementerian Ketenagakerjaan.

Model penelitian dalam penelitian ini digambarkan sebagai berikut: 


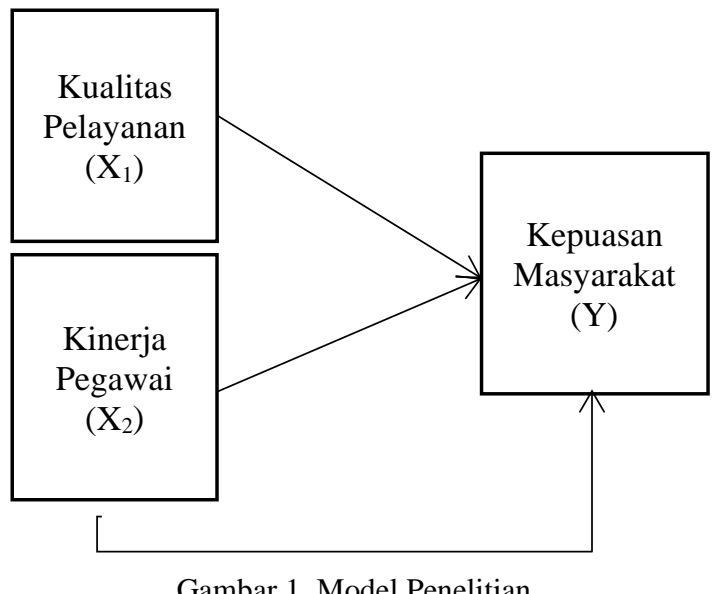

Gambar 1. Model Penelitian

\section{METODOLOGI PENELITIAN}

Jenis Penelitian dalam penelitian ini menggunakan pendekatan penelitian kuantitatif. Penelitian dilakukan pada unit Pelayanan Terpadu Satu Atap (PTSA) Kementerian Ketenagakerjaan. Unit PTSA itu sendiri keberadaanya di gedung Kementerian Ketenagakerjaan yang beralamat di Jalan Jenderal Gatot Subroto Kav. 51, Jakarta Selatan.

Penelitian ini populasinya semua masyarakat yang menerima layanan untuk melakukan pengurusan pengesahan terkait dengan Peraturan Perusahaan dan Pendaftaran Perjanjian Kerja Bersama di unit PTSA Kementerian Ketenagakerjaan. Sedangkan untuk sampel mengambil dengan teknik non probability sampling dimana jenisnya dengan menggunakan accidental sampling. Sampel diperoleh sebanyak 45 orang yaitu masyarakat yang datang di unit PTSA dan secara kebetulan bertemu peneliti.

Penelitian ini menggunakan kuesioner dalam metode mengumpulkan datanya. Menurut (Noor, 2013) "kuesioner adalah teknik pengumpulan data dengan memberikan atau menyebarkan daftar pertanyaan kepada responden dengan harapan memberikan respons atas daftar pertanyaan tersebut”.

Menurut (Soegoto, 2008) “alat ukur atau yang disebut instrument dalam penelitian menggunakan pendekatan kuantitatif harus mempunyai validitas/kesahihan dan reliabilitas/dapat dipercaya secara ilmiah”. Analisis data yang digunakan dalam penelitian ini menggunakan uji regresi dengan dua variabel bebas dan satu variabel terikat yang teknik pengolahan memakai program komputer SPSS 25.0. Variabel bebas terdiri dari variabel kualitas pelayanan dan variabel kinerja pegawai, sedangkan kepuasan masyarakat sebagai variabel terikat.

\section{HASIL DAN PEMBAHASAN}

Dalam uji validitas yang dilakukan dengan jumlah 45 responden sebagai sampel diperoleh nilai $\mathrm{r}$ tabel sebesar 0,301. Berikut hasil uji validitas variabel kualitas pelayanan:

Tabel 1. Uji Validitas Kualitas Pelayanan

\begin{tabular}{|c|c|c|}
\hline $\begin{array}{c}\text { No. Butir } \\
\text { pertanyaan }\end{array}$ & rhitung & rtabel \\
\hline 1 & 0,417 & \multirow{2}{*}{0,301} \\
\hline 2 & 0,653 & \\
\hline 3 & 0,821 & \\
\hline 4 & 0,893 & \\
\hline 5 & 0,811 & \\
\hline 6 & 0,835 & \\
\hline 7 & 0,798 & \\
\hline 8 & 0,757 \\
\hline 9 & 0,623 \\
\hline 10 & 0,692 \\
\hline
\end{tabular}

Sumber: Hasil Pengolahan Data Penelitian, 2019

Pada tabel 1 menunjukkan untuk variabel kualitas pelayanan dari 10 pertanyaan dinyatakan valid karena dimana $r$ hitung lebih besar dari $r$ tabel. Berikut adalah tabel yang menunjukkan hasil uji validitas varaibel kinerja pegawai:

Tabel 2. Uji Validitas Kinerja Pegawai

\begin{tabular}{|c|c|c|}
\hline $\begin{array}{c}\text { No. Butir } \\
\text { Pertanyaan }\end{array}$ & rhitung & rtabel \\
\hline 1 & 0,430 & \multirow{2}{*}{0,301} \\
\hline 2 & 0,541 & \\
\hline 3 & 0,767 & \\
\hline 4 & 0,806 & \\
\hline 5 & 0,480 & \\
\hline 6 & 0,841 \\
\hline 7 & 0,843 \\
\hline 8 & 0,852 \\
\hline 9 & 0,883 \\
\hline
\end{tabular}

Sumber: Hasil Pengolahan Data Penelitian, 2019

Dari tabel 2, dapat dilihat bahwa dari 9 butir pertanyaan dinyatakan valid dimana $r$ hitung yang dihasilkan semuanya lebih besar dari $r$ tabel. Untuk uji validitas kepuasan masyarakat dapat di lihat pada tabel dibawah ini: 
Tabel 3. Uji Validitas Kepuasan Masyarakat

\begin{tabular}{|c|c|c|}
\hline $\begin{array}{c}\text { No. Butir } \\
\text { pertanyaan }\end{array}$ & rhitung & rtabel \\
\hline 1 & 0,633 & \multirow{2}{*}{0,301} \\
\hline 2 & 0,746 & \\
\hline 3 & 0,763 \\
\hline 4 & 0,785 \\
\hline 5 & 0,704 \\
\hline 6 & 0,745 \\
\hline 7 & 0,781 \\
\hline 8 & 0,720 \\
\hline 9 & 0,440 \\
\hline 10 & 0,425 \\
\hline
\end{tabular}

Sumber: Hasil Pengolahan Data Penelitian, 2019

Pada tabel 3, dapat ditunjukkan bahwa pertanyaan yang jumlahnya 10 butir mengenai variabel kepuasan masyarakat seluruhnya valid dengan $r$ hitung nilainya lebih besar dari r tabel.

Untuk reliabilitas variabel penelitian menggunakan rumus Cronbach's Alpha. Apabila nilainya lebih dari 0,60 , maka pertanyaan yang diajukan dalam kuesioner dinyatakan reliabel. Dapat diketahui bahwa semua varibel sudah reliabel dengan Cronbach's Alpha pada masing-masing variabel melebihi nilai 0,60 . Hal tersebut dapat terlihat pada tabel Berikut:

Tabel 4. Uji Reliabilitas

\begin{tabular}{|l|l|}
\hline Variabel & Cronbach's Alpha \\
\hline Kualitas pelayanan & 0,907 \\
\hline Kinerja pegawai & 0,886 \\
\hline Kepuasan Masyarakat & 0,868 \\
\hline
\end{tabular}

Sumber: Hasil pengolahan Data Penelitian, 2019

Berdasarkan uji normalitas galat diketahui bahwa grafik histogram mengikuti distribusi normal dan dari gambar 2. P-P Plot test titik-titiknya berada digaris diagonal serta searah dengan garis sehingga data berdistribusi normal. Lebih jelasnya uji normalitas galat dapat diketahui melalui gambar di bawah ini:

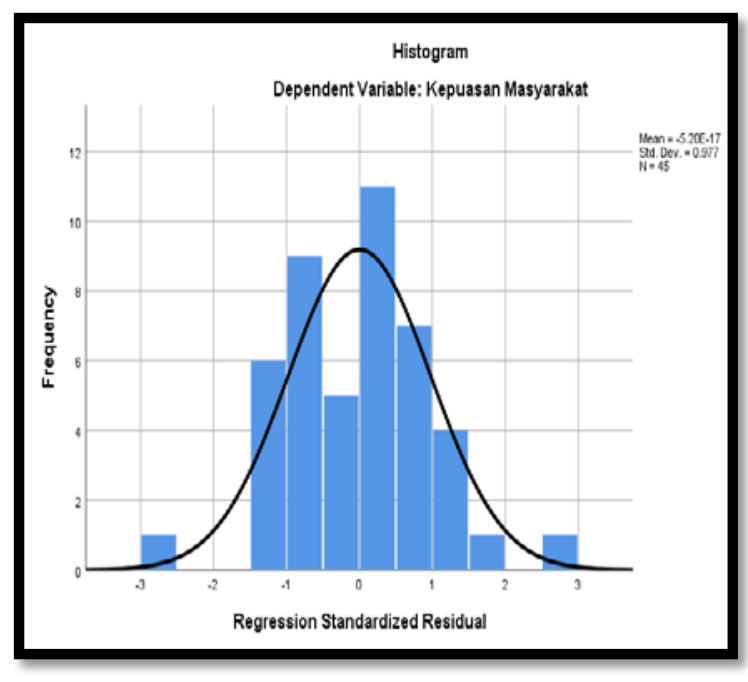

Gambar 2. Histogram

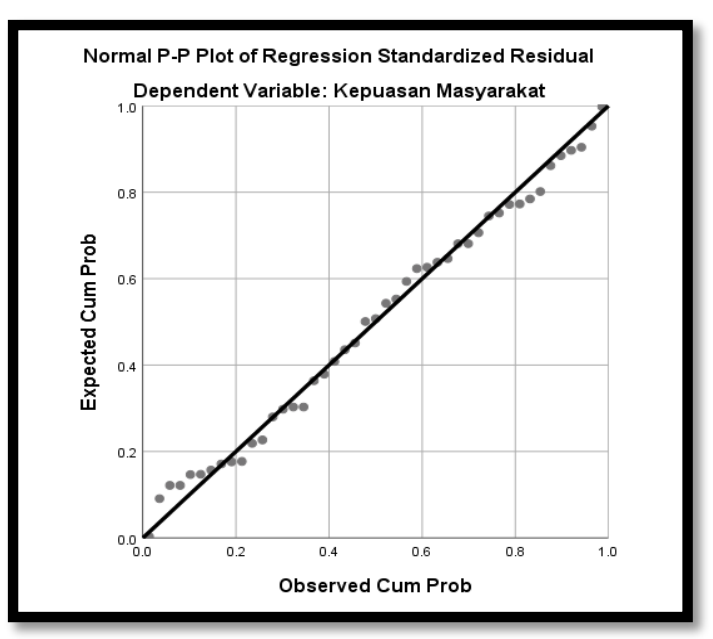

Gambar 3. Normal Probability Plot dilakukan:

Berikut adalah tabel hasil uji linieritas yang

Tabel 5. Hasil Uji Linearitas Kualitas Pelayanan dengan Kepuasan Masyarakat

\begin{tabular}{|c|c|c|c|c|c|c|c|}
\hline \multicolumn{8}{|c|}{ ANOVA Table } \\
\hline & & & $\begin{array}{l}\text { Sum } \\
\text { of } \\
\text { Squa } \\
\text { res }\end{array}$ & $\begin{array}{l}\mathrm{D} \\
\mathrm{f}\end{array}$ & $\begin{array}{c}\text { Me } \\
\text { an } \\
\text { Squ } \\
\text { are }\end{array}$ & $\mathrm{F}$ & $\begin{array}{l}\mathrm{S} \\
\mathrm{i} \\
\mathrm{g} \\
.\end{array}$ \\
\hline \multirow{13}{*}{$\begin{array}{l}\text { Kep } \\
\text { uasa } \\
\mathrm{n} \\
\text { Mas } \\
\text { yara } \\
\text { kat } \\
* \\
\text { Kua } \\
\text { litas } \\
\text { Pela } \\
\text { yan } \\
\text { an }\end{array}$} & \multirow{3}{*}{$\begin{array}{l}\mathrm{B} \\
\text { et } \\
\mathrm{W}\end{array}$} & (Com & 548.88 & 1 & 36.59 & 2.3 & .02 \\
\hline & & bined & 3 & 5 & 2 & 90 & 1 \\
\hline & & ) & & & & & \\
\hline & e & Lin & 399. & 1 & 399 & 2 & . \\
\hline & $\mathrm{e}$ & eari & 873 & & .87 & 6 & 0 \\
\hline & $\mathrm{n}$ & ty & & & 3 & . & 0 \\
\hline & $\mathrm{G}$ & & & & & 1 & 0 \\
\hline & $r$ & & & & & 2 & \\
\hline & 0 & & & & & 3 & \\
\hline & $\mathrm{u}$ & De & 149. & 1 & 10. & $\cdot$ & $\cdot$ \\
\hline & $\mathrm{p}$ & viat & 010 & 4 & 644 & 6 & 7 \\
\hline & $\mathrm{S}$ & ion & & & & 9 & 6 \\
\hline & & $\begin{array}{l}\text { fro } \\
\text { m }\end{array}$ & & & & 5 & 1 \\
\hline
\end{tabular}




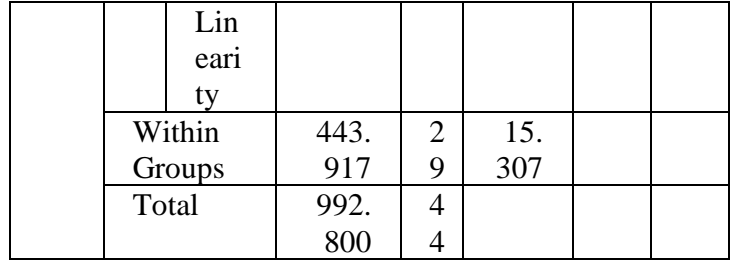

Nilai Sig baris Deviation from Linearity $=$ 0,761 lebih besar daripada 0,05 yang menunjukkan bahwa ada linearitas antara kualitas pelayanan dan kepuasan masyarakat.

Tabel 6. Uji Linearitas Kinerja Pegawai dengan Kepuasan Masyarakat



Untuk nilai Sig baris Deviation from Linearity adalah 0,775 lebih besar dari 0,05 yang artinya kinerja pegawai dengan kepuasan masyarakat ada linearitas.

Untuk uji heteroskedastisitas dapat dilihat dengan gambar di bawah ini dimana diketahui tidak terdapat heteroskedastisitas pada penelitian ini karena titik pada grafik tersebar acak di sumbu Y baik diatas atau dibawah angka 0 .

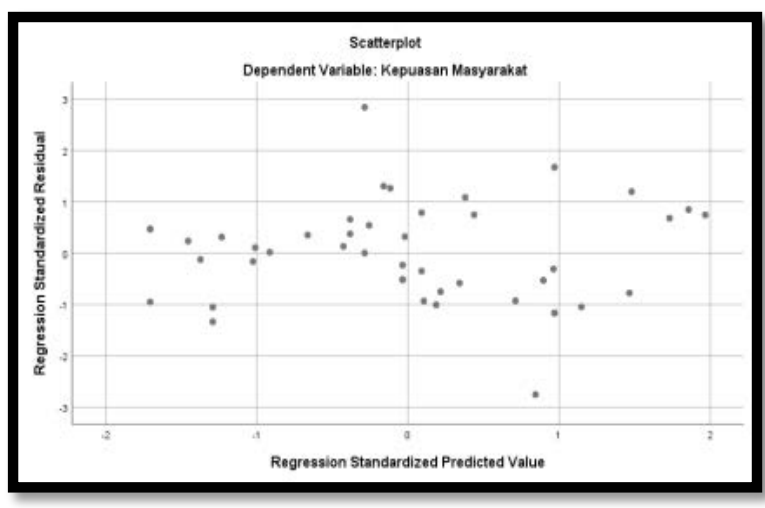

Gambar 4. Uji Heteroskedastisitas

Untuk uji multikolinearitas nilai tolerance lebih kecil dari 1 dan nilai VIF juga dekat dengan 1 sehingga tidak terdapat multikolinearitas antara variabel kualitas pelayanan dan varibel kinerja pegawai. Hal ini dapat diihat pada tabel berikut:

Tabel 7. Uji Multikolinearitas

\begin{tabular}{|l|r|c|}
\hline \multicolumn{1}{|c|}{ Variabel Indepedent } & Tolerance & \multicolumn{1}{c|}{ VIF } \\
\hline Kualitas Pelayanan &, 702 & 1,424 \\
\hline Kinerja Pegawai &, 702 & 1,424 \\
\hline
\end{tabular}

Berikut adalah hasil koefisien korelasi dan koefisien determinasi yang ditunjukkan pada tabel di bawah ini:

Tabel 8. Hasil Model Summary

Model Summary

\begin{tabular}{|c|c|c|c|c|c|c|c|c|}
\hline \multicolumn{9}{|c|}{ Model Summary } \\
\hline \multirow{5}{*}{$\begin{array}{l}\text { Mo } \\
\text { del }\end{array}$} & \multirow[t]{5}{*}{$\mathrm{R}$} & \multirow{2}{*}{$\begin{array}{l}\mathrm{R} \\
\mathrm{Sq}\end{array}$} & \multirow{2}{*}{$\begin{array}{l}\text { Adjus } \\
\text { ted R }\end{array}$} & \multirow{2}{*}{$\begin{array}{l}\text { Std. } \\
\text { Error }\end{array}$} & \multicolumn{4}{|c|}{ Change Statistics } \\
\hline & & & & & $\mathrm{R}$ & $\mathrm{F}$ & df $\quad$ df2 & Sig. \\
\hline & & uar & Squar & of the & Square & Ch & 1 & $\mathrm{~F}$ \\
\hline & & e & $\mathrm{e}$ & Estimat & Chang & ang & & Cha \\
\hline & & & & $\mathrm{e}$ & $\mathrm{e}$ & $\mathrm{e}$ & & nge \\
\hline 1 & $.690^{\circ}$ & .476 & .451 & 3.521 & .476 & $\begin{array}{l}19.042 \\
2\end{array}$ & 242 & .000 \\
\hline
\end{tabular}

a. Predictors: (Constant), Kinerja Pegawai, Kualitas Pelayanan

b. Dependent Variable: Kepuasan Masyarakat

Nilai koefisien korelasi menunjukkan nilai 0,690 yang berarti ada hubungan kuat antara kualitas pelayanan dan kinerja pegawai dengan kepuasan masyarakat di unit PTSA Kementerian Ketenagakerjaan. Koefisien determinasi bernilai 0,476 menunjukkan sumbangan kualitas pelayanan dan kinerja pegawai terhadap kepuasan masyarakat di unit PTSA Kementerian Ketenagakerjaan adalah $47,6 \%$ sedangkan yang dipengaruhi faktor lainnya adalah 52,4\%.

Tabel dibawah adalah hasil uji persamaan regresi yang telah dilakukan beserta hasil uji t: 
Tabel 9. Hasil Persamaan Linear Regresi Ganda dan Hasil Uji t

\begin{tabular}{|c|c|c|c|c|c|c|}
\hline \multicolumn{7}{|c|}{ Coefficients $^{\mathrm{a}}$} \\
\hline \multirow{3}{*}{\multicolumn{2}{|c|}{ Model }} & \multirow{2}{*}{\multicolumn{2}{|c|}{$\begin{array}{l}\text { Unstandardiz } \\
\text { ed } \\
\text { Coefficients }\end{array}$}} & \multirow{3}{*}{$\begin{array}{c}\text { Standardi } \\
\text { zed } \\
\text { Coefficie } \\
\text { nts } \\
\text { Beta }\end{array}$} & \multirow[t]{3}{*}{$\mathrm{T}$} & \multirow{3}{*}{$\begin{array}{l}\mathrm{S} \\
\mathrm{i} \\
\mathrm{g}\end{array}$} \\
\hline & & & & & & \\
\hline & & B & $\begin{array}{c}\text { Std. } \\
\text { Erro } \\
\text { r }\end{array}$ & & & \\
\hline \multirow[t]{3}{*}{1} & $\begin{array}{l}\text { (Const } \\
\text { ant) }\end{array}$ & $\begin{array}{c}10.45 \\
0\end{array}$ & 5.062 & & $\begin{array}{c}2.06 \\
5\end{array}$ & $\begin{array}{c}.04 \\
5\end{array}$ \\
\hline & $\begin{array}{l}\text { Kualit } \\
\text { as } \\
\text { Pelaya } \\
\text { nan }\end{array}$ & .412 & .120 & .459 & $\begin{array}{c}3.44 \\
2\end{array}$ & $\begin{array}{c}.00 \\
1\end{array}$ \\
\hline & $\begin{array}{l}\text { Kinerj } \\
\text { a } \\
\text { Pegaw } \\
\text { ai }\end{array}$ & .363 & .151 & .322 & $\begin{array}{c}2.41 \\
4\end{array}$ & $\begin{array}{c}.02 \\
0\end{array}$ \\
\hline & epend & $\mathrm{ab}$ & Kepua & Masyarakat & & \\
\hline
\end{tabular}

Berdasarkan tabel 9. variabel kualitas pelayanan dan variabel kinerja pegawai hasil koefisien regresi adalah positif. Lebih jelasnya dapat diketahui melalui persamaan regresi linier berganda berikut ini:

$$
\mathrm{Y}=10,450+0,412 \mathrm{X}_{1}+0,363 \mathrm{X}_{2}
$$

Untuk $\mathrm{t}$ hitung kualitas pelayanan adalah 3,442 dengan nilai sig 0,001, berarti kepuasan masyarakat di unit PTSA Kementerian Ketenagakerjaan secara signifikan dipengaruhi oleh kualitas pelayanan. Sedangkan t hitung kinerja pegawai ditunjukkan dengan angka 2,414 dan nilai sig 0,020. Jadi, kepuasan masyarakat di unit PTSA Kementerian Ketenagakerjaan secara signifikan juga dipengaruhi kinerja pegawai.

Tabel 10. Hasil Uji Persamaan Regresi Linear Ganda

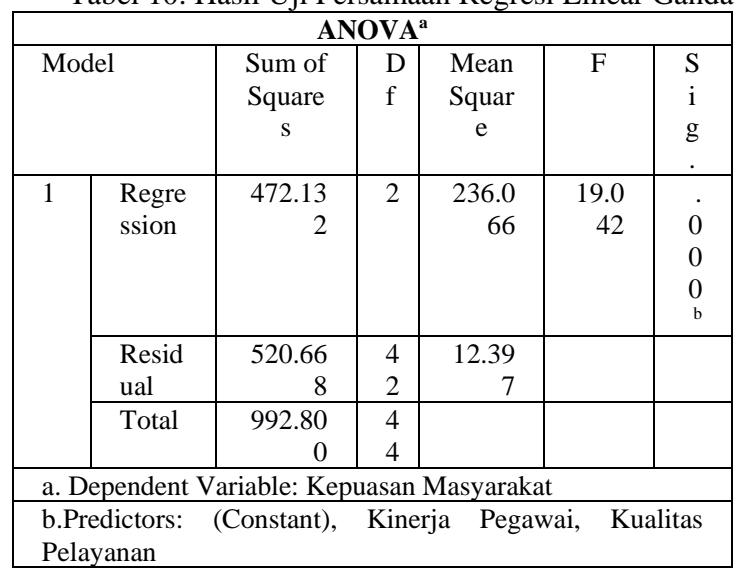

Berdasarkan tabel 10. nilai F hitung diperoleh angka 19,042 dengan nilai sig 0,000. Berarti, secara simultan kualitas pelayanan dan kinerja pegawai memiliki pengaruh yang signifikan pada kepuasan masyarakat di unit PTSA Kementerian Ketenagakerjaan.

Dari hasil perhitungan diatas dapat diketahui bahwa kepuasan masyarakat di unit PTSA Kementerian Ketenagakerjaan positif dan signifikan terhadap baik secara parsial dan simultan oleh kualitas pelayanan dan kinerja pegawai. Hasil ini dapat memberikan gambaran bahwa semakin baik dan adanya peningkatan kualitas pelayanan dan kinerja pegawai maka kepuasan masyarakat di unit PTSA Kementerian Ketenagakerjaan juga semakin baik dan mengalami peningkatan. Penelitian yang dilakukan hasilnya juga selaras dengan referensi yang dipakai yaitu dalam buku (Tjiptono, 2008) dan (Wibowo, 2009) dan penelitian yang telah dilakukan oleh (Siswadhi, 2016), (Noer \& Putri, 2013), (Karyono \& Parman, 2016), (Kuncoro, 2017), (Ulumudin, 2014) yang menunjukkan hasil penelitiannya dimana kepuasan masyarakat dipengaruhi oleh adanya kualitas pelayanan maupun kinerja pegawai.

\section{KESIMPULAN}

Dari penelitian ini dapat disimpulkan secara parsial maupun simultan kualitas pelayanan dan kinerja pegawai memliki pengaruh yang positif dan signifikan terhadap kepuasan masyarakat di unit PTSA Kementerian Ketenagakerjaan. Unit PTSA Kementerian Ketenagakerjaan dalam memberikan pelayanannya tersebut diharapkan terus konsisten, lebih memudahkan prosedur pelayanan, dan kepentingan masyarakat selalu diutamakan. Sedangkan kinerja pegawai dapat ditingkatkan lagi dengan tetap bekerja lebih profesional dan sesuai aturan yang berlaku, selalu mengevaluasi hasil pekerjaan yang telah dilakukan sehingga ada perbaikan kedepannya, dan pegawai terus meningkatkan pengetahuan dan keterampilan dalam bidang kerjanya dengan mengembangkan kreativitas dalam menyelesaikan kesulitan masyarakat. Tanggung jawab terhadap masyarakat dalam memenuhi kepuasan masyarakat diharapkan tetap menjadi prioritas sehingga pemenuhan kebutuhan dan keinginan masyarakat yang meminta pelayanan dapat diberikan dengan layanan yang lebih prima atau istimewa yang tentunya dengan hasil yang tepat dan cermat sehingga kepuasan masyarakat terus meningkat. Koefisien determinasi 0,476 menunjukkan bahwa kualitas pelayanan dan kinerja pegawai memberikan sumbangan 47,6 \% terhadap kepuasan masyarakat dan sisanya 52,4\% dipengaruhi oleh faktor lain sehingga perlu dilakukan penelitian yang lebih lanjut dengan faktor lain yang diduga bisa mempengaruhi kepuasan masyarakat di unit PTSA Kementerian Ketenagakerjaan.

\section{REFERENSI}

Hermawati. (2018). Pengaruh Kompetensi Pegawai, Kualitas Pelayanan Dan Disiplin Kerja Terhadap Kepuasan Pelanggan Pada Kantor UPT Pendapatan Wilayah Makassar 01 Selatan, Provinsi Sulawesi Selatan. Jurnal Mirai Management, 3(1), 87-100.

Iqbal. (2016). PTSA Kemnaker Melayani Tanpa 
Memungut Biaya. Progresnews.Info. Retrieved from http://progresnews.info/2016/10/12/ptsakemnaker-melayani-tanpa-memungut-biaya/ Karyono, O., \& Parman, M. (2016). Kepuasan Nasabah Diukur dari Kinerja Pelayanan dan Kinerja Karyawan. Jurnal J-Ensitec, 02(02), 32-37.

Kementerian Pendayagunaan Aparatur Negara Republik Indonesia. Keputusan Pendayagunaan Aparatur Negara Nomor: 63/KEP/M.PAN/7/2003 Tentang Pedoman Umum Penyelenggaraan Pelayanan Publik. , (2003).

Kuncoro, S. B. (2017). Pengaruh Kualitas Pelayanan Dan Semangat Kerja Pegawai Terhadap Kepuasan Masyarakat di Kantor Kecamatan Bengalon Kabupaten Kutai Timur. EJournal Pemerintahan Integratif, 5(2), 234-245.

Mangkunegara, A. A. A. P. (2009). Evaluasi Kinerja SDM. Bandung: PT Refika Aditama.

Mukarom, Z., \& Laksana, M. W. (2015). Manajemen Pelayanan Publik. Bandung: Pustaka Setia.

Noer, S., \& Putri, E. (2013). Pengaruh Kualitas Pelayanan dan Kinerja Karyawan terhadap Kepuasan Pelanggan (Study pada Universitas Muhammadiyah Surakarta). 226-233.

Noor, J. (2013). Metodologi Penelitian: Skripsi, Tesis, Disertasi, dan Karya Ilmiah (Edisi Pert). Jakarta: Kencana.

Prawirosentono, S. (1999). Manajemen Sumber
Daya Manusia : Kebijakan Kinerja Karyawan. Yogyakarta: BPFE.

Putra, D. G., Pratiwi, R. N., \& Trisnawati. (2015). Pengaruh Kualitas Pelayanan Terhadap Kepuasan Masyarakat (Studi pada Dinas Kependudukan dan Pencatatan Sipil Kota Blitar). Jurnal Administrasi Publik (JAP), 3(12), 2118-2122.

Ratminto, \& Winarsih Atik Septi. (2015). Manajemen Pelayanan. Yogyakarta: Pustaka Pelajar.

Siswadhi, F. (2016). Analisa Pengaruh Kualitas Pelayanan Dan Kinerja Karyawan Badan Pertanahan Nasional Kabupaten Kerinci Terhadap Kepuasan Masyarakat. Jurnal Benefita, 1(3), 177-183. https://doi.org/10.22216/jbe.v1i3.720

Soegoto, E. S. (2008). Marketing Research The Smart Way to Solve A Problem. Jakarta: PT Elex Media Komputindo.

Tjiptono, F. (2008). Service Management Mewujudkan Layanan Prima. Yogyakarta: Andi Offset.

Ulumudin, A. (2014). Pengaruh Kualitas Pelayanan Administrasi Kependudukan terhadap Kepuasan Masyarakat di Kecamatan Bayongbong Kabupaten Garut. Jurnal Pembangunan Dan Kebijakan Publik, 04(01), $1-6$.

Wibowo. (2009). Manajemen Kinerja. Jakarta: PT RajaGrafindo Persada. 